\title{
MEMOIR
}

\section{ARTHUR GEORGE HEMMING}

WE record, with the greatest regret, the death on 28 January 195 I of Arthur George Hemming, at the age of 84 . Hemming, who was born on 12 July 1866 , won, in $\mathrm{x} 880$, an entrance scholarship in Mathematics and entered Rugby School. He inherited his great mathematical ability from his father, Gcorge Wirgman Hemming, K.C., who was Senior Wrangler at Cambridge in 1844 .

Hemming left Rugby in $\mathrm{I} 883$ and joined the staff of the Northern Assurance Company. His mathematical ability was of such a high quality that he became a Fellow of the Institute of Actuaries at the age of 21 .

In 1891 he was appointed Assistant Secretary in London of the Scottish Widows' Fund and in I894 became London Secretary of the City of Glasgow. He was appointed Assistant Actuary of the London Assurance in 1899 , becoming Actuary in rgor. In this appointment he succeeded Arthur Hutcheson Bailey (I 86I-95) and George King (I896-I90I). In 1922 he became Actuary and Manager of the Life Department, which appointment he held until he retired in $193 \mathrm{I}$.

Hemming served as an Examiner for the Institute of Actuaries and was a member of the Council.

He was very interested in a country life and became an expert horticulturist, specializing in the genera Primula and Meconopsis.

In the early part of the present century, whilst visiting the South Downs, he joined with his wife in collecting neolithic stone implements. He became so keen that he decided to extend his field of study to those of Palaeolithic age found in the Thames river gravels. At this time he was keenly interested in a controversy regarding the alleged stone implements of the so-called Eolithic age. During this time he was rapidly building up one of the finest collections of English stone implements ever assembled. He further extended his interests in this direction to cover corresponding European stone implements, and paid special visits to notable sites on the Continent.

He soon realizcd that valuable light might be thrown on early stone implements by a study of those of more modern date made by the peoples of the Pacific. He decided, therefore, to extend the scope of his collections to cover stone implements of all ages in any part of the world. Later he decided to extend his intercsts by making a large collection of objects in wood, stone and other materials illustrating the cultures of primitive people. For his work in these fields he was elected to the Fellowship of the Royal Anthropological Institute and contributed a number of interesting and valuable papers to the Institute's Journal Man.

$\Lambda$ part from his anthropological studies he was keenly interested in Medieval bronze manufactures, and formed a unique collection of bronze mortars. It had always been known that bell founders manufactured pestles and mortars for the use of apothecaries, but this aspect of their work had never been intensely studied; Hemming therefore proceeded to collect information regarding design and workmanship which would identify particular bell founders with particular types of mortar. The results of his investigations were published in the Connoisseur and elsewhere. He was an expert photographer, and the value of these articles was greatly enhanced by the photographs which he took.

In addition to these interests he was a keen conchologist and with his wife made a fine collection of shells. His collection was particularly rich in the shells of Tropical Gastropods, notably of the genera Cypraea and Valuta.

A. G. P. 